\title{
Evaluation of the Heavy Metals in Tonic Creams using the Wet Acid and Dry Ashing Methods
}

\section{Emmanuel Orimisan Abata*, Oluwasanmi Damilola Ogunkalu, Adewale Abdulahi Adeoba and Olugbenga Oludayo Oluwasina}

Chemistry Department, Federal University of Technology, PMB 704, Akure, Nigeria

e-mail: eabata@futa.edu.ng, ogunkaludamilola@gmail.com, hardwhale01@gmail.com, oooluwasina@futa.edu.ng

*Corresponding author

\section{Abstract}

It has recently been discovered that long term exposure to heavy metals such as mercury $(\mathrm{Hg})$, lead $(\mathrm{Pb})$, cadmium $(\mathrm{Cd})$, and nickel $(\mathrm{Ni})$ causes some health which are carcinogenic, behavioral abnormalities and sterility. This study is aimed at determining the concentration of $\mathrm{Pb}, \mathrm{Cd}, \mathrm{Zn}, \mathrm{Mn}, \mathrm{Cr}, \mathrm{Cu}$ and $\mathrm{Ni}$ in skin cosmetics, particularly in toning creams. Samples were purchased from Oja-Oba market in Akure City of Ondo state, Nigeria. All the heavy metals under study were quantified using atomic absorption spectroscopy (AAS) after wet digestion and dry ashing methods. The following metals were found through wet digestion, $\mathrm{Cu}$ (3.90-12.05), $\mathrm{Zn}$ (3.50-7.10), $\mathrm{Mn}$ (9.90-12.50), $\mathrm{Cd}$ (0.00-0.35), Ni (1.05-2.25), Pb (0.10-1.80) and $\mathrm{Cr}$ (0.6-4.1) while dry ashing recorded, $\mathrm{Cu}$ (7.15-10.70), Zn (6.40-13.85), Mn (10.60-14.90), Cd (0.35-0.55), Ni (3.40-4.70), Pb $(0.30-0.55)$ and $\mathrm{Cr}(0.85-1.00) \mathrm{mg} / \mathrm{kg}$. It was observed that the concentrations of those metals in the creams investigated were below the maximum permissible limits set by WHO. Significant differences $(p<0.05)$ of the levels of heavy metals were found between some of the creams posing risks of a combination of creams as well as continual usage. It is, therefore, necessary to indicate the levels of heavy metals on the labels of these cosmetics so the users can be aware.

Received: January 11, 2019; Accepted: January 22, 2019

Keywords and phrases: heavy metals, cosmetic, atomic absorption spectroscopy, toxicity.

Copyright (C) 2019 Emmanuel Orimisan Abata et al. This is an open access article distributed under the Creative Commons Attribution License, which permits unrestricted use, distribution, and reproduction in any medium, provided the original work is properly cited. 


\section{Introduction}

Cosmetic products are used by all caste of society as a part of routine body care. Previously, metals were major ingredients of cosmetics, for example, preservative thimerosal (mercury), lead acetate, and red cinnabar (mercuric sulphide) are usually added as progressive hair dye in a number of tattoo pigments (Omolaoye et al. [12]). Heavy metals are elements that have densities greater than $5 \mathrm{~g} / \mathrm{cm}^{3}$ which include cadmium, chromium, cobalt, copper, iron, lead, manganese, mercury, molybdenum, nickel, tin and zinc. When heavy metals are present at certain concentrations, it results in being toxic. This is due to the fact that some metals can accumulate in the body over time and are caused by different long-term health effects which can include cancer, reproductive and developmental and neurological disorders, cardiovascular, kidney and renal problems, lung damage, contact dermatitis, and brittle hair and hair loss. Many are suspected hormone disruptors and respiratory toxins. $\mathrm{Co}, \mathrm{Cr}$ and $\mathrm{Ni}$ are potent skin sensitizers, while $\mathrm{As}, \mathrm{Cd}, \mathrm{Hg}, \mathrm{Pb}, \mathrm{Sb}$ are highly toxic with many long-term effects (Forte et al. [7], Thyssen et al. [13]). Exposure to these metals, however, keeps increasing daily especially in cosmetics. Cosmetics which are substances that are rubbed, poured, sprinkled or introduced into the human body to clean, beautify, promote attractiveness or alter appearance have been found to contain certain heavy metals. Skin care products, basically creams can be classified as lightening creams (including the bleaching and toning creams) and moisturizers (Kasture et al. [10]). Since testing is not made mandatory and manufacturers have control over it, many cosmetics products ingredients are not safety tested at all. Therefore, this work is aimed at evaluating the heavy metals found in some creams in Nigeria.

\section{Materials and Methods}

\subsection{Material}

The three lotion creams were bought at Oja Oba, Akure, Nigeria.

\subsection{Methods}

\subsubsection{Digestion of samples and blanks}

The samples were digested using dry ashing and wet digestion methods. 


\subsubsection{Wet acid digestion}

About $5.0 \mathrm{~g}$ of lotion was accurately measured into a conical flask. Then, $15 \mathrm{ml}$ concentrated Nitric acid was added followed by $5 \mathrm{ml} 30 \%$ v/v Hydrogen peroxide and then $5 \mathrm{ml}$ concentrated Hydrochloric acid. The flask was closed and left for 15 minutes to ensure complete reaction. The mixture was heated at $150^{\circ} \mathrm{C}$ for about three hours until no more brown fumes were produced. $5 \mathrm{ml}$ of $0.5 \mathrm{M} \mathrm{HNO}_{3}$ was then added after which the solution was warmed slightly. The sample solution was then cooled and $20 \mathrm{ml}$ of deionized water added. The solution was filtered through Whatman paper number 42 into a $50 \mathrm{ml}$ volumetric flask and diluted to volume with deionized water before aspiration into the instrument. Aspirations were performed in triplicate in each case to ensure precision. In order to account for the background effects from the acids and to correct for changes resulting from digestion procedures, the above procedure was used to digest a blank. The process was employed in the digestion of all the 3 samples.

\subsubsection{Dry ashing}

The crucibles intended for use were pre-heated in an oven at an increasing temperature for 45 minutes until the temperature gets to $105^{\circ} \mathrm{C}$. The crucibles were brought out of the oven and transferred into a desiccator for 30 minutes until it cools. The cooled crucibles were measured and recorded and about $5 \mathrm{~g}$ of each of the samples were placed in the crucibles and this was done in triplicates. The sample was pre-heated on a hot-plate in the fume hood to give off most of its organic content. The pre-heated sample was then transferred inside the furnace at $480^{\circ} \mathrm{C}$ for about $6 \mathrm{~h}$ until grey ash residue was obtained. The samples were removed from the furnace and placed in the desiccator until it cools and $10 \mathrm{ml}$ of $5 \mathrm{M} \mathrm{HNO}_{3}$ was added and filtered through Whatman No. 42 filter paper and then transferred quantitatively into a $50 \mathrm{ml}$ plastic container.

\subsection{Measurement of metal concentration}

The samples were digested in triplicates and analyzed using Atomic Absorption Spectrophotometer (AAS) Buck Scientific 210 VGP which is a flame atomic absorption spectrophotometer (FAAS). 


\section{Results and Discussions}

\subsection{Results}

Table 3.1. Mean levels $(\mathrm{mg} / \mathrm{kg})$ of heavy metals in toning creams using the wet acid method of digestion.

\begin{tabular}{llllllll}
\hline & $\mathbf{C u}$ & $\mathbf{Z n}$ & $\mathbf{M n}$ & $\mathbf{C d}$ & $\mathbf{N i}$ & $\mathbf{P b}$ & $\mathbf{C r}$ \\
$\mathbf{A}$ & $3.90^{\mathrm{a}} \pm 0.14$ & $3.50^{\mathrm{a}} \pm 0.14$ & $9.90^{\mathrm{a}} \pm 0.14$ & $\mathrm{Bdl}$ & $9.90^{\mathrm{b}} \pm 0.14$ & $1.05^{\mathrm{a}} \pm 1.48$ & $4.15^{\mathrm{b}} \pm 0.07$ \\
$\mathbf{B}$ & $7.90^{\mathrm{b}} \pm 0.12$ & $7.10^{\mathrm{a}} \pm 1.70$ & $11.35^{\mathrm{a}} \pm 2.3$ & $0.20^{\mathrm{a}} \pm 0.14$ & $1.05^{\mathrm{a}} \pm 0.35$ & $1.40^{\mathrm{a}} \pm 2.00$ & $1.25^{\mathrm{a}} \pm 1.06$ \\
$\mathbf{C}$ & $12.05^{\mathrm{c}} \pm 0.35$ & $3.6^{\mathrm{a}} \pm 0.57$ & $12.50^{\mathrm{a}} \pm 2.26$ & $0.35^{\mathrm{a}} \pm 0.21$ & $2.25^{\mathrm{b}} \pm 1.20$ & $0.10^{\mathrm{b}} \pm 0.14$ & $0.60^{\mathrm{a}} \pm 0.14$ \\
\hline
\end{tabular}

$\mathrm{A}, \mathrm{B}$ and $\mathrm{C}=$ Different Samples; (Bdl = below detection limit). Data are presented as Mean $\pm \mathrm{SD}(n=3)$. Values with the same superscript letter down the columns are not significantly different $(p>0.05)$.

Table 3.2. Mean levels $(\mathrm{mg} / \mathrm{kg})$ of heavy metals in toning creams using dry ashing method of digestion.

\begin{tabular}{lllllllll}
\hline & $\mathbf{C u}$ & $\mathbf{Z n}$ & $\mathbf{F e}$ & $\mathbf{M n}$ & $\mathbf{C d}$ & $\mathbf{N i}$ & $\mathbf{P b}$ & $\mathbf{C r}$ \\
$\mathbf{E}$ & $10.25^{\mathrm{a}} \pm 0.35$ & $6.40^{\mathrm{a}} \pm 2.55$ & $19.85^{\mathrm{a}} \pm 0.35$ & $11.65^{\mathrm{a}} \pm 1.06$ & $0.35^{\mathrm{a}} \pm 0.30$ & $3.40^{\mathrm{a}} \pm 0.99$ & $0.55^{\mathrm{a}} \pm 0.31$ & $0.85^{\mathrm{ab}} \pm 0.21$ \\
$\mathbf{F}$ & $10.70^{\mathrm{a}} \pm 0.57$ & $13.85^{\mathrm{a}} \pm 8.27$ & $20.90^{\mathrm{a}} \pm 0.28$ & $14.90^{\mathrm{a}} \pm 3.82$ & $0.55^{\mathrm{a}} \pm 0.35$ & $4.70^{\mathrm{a}} \pm 2.21$ & $0.30^{\mathrm{a}} \pm 0.00$ & $0.90^{\mathrm{ab}} \pm 0.00$ \\
$\mathbf{H}$ & $7.15^{\mathrm{a}} \pm 0.21$ & $8.80^{\mathrm{a}} \pm 0.28$ & $14.70^{\mathrm{a}} \pm 1.27$ & $10.60^{\mathrm{a}} \pm 0.28$ & $0.45^{\mathrm{a}} \pm 0.40$ & $4.30^{\mathrm{a}} \pm 2.69$ & $0.45^{\mathrm{a}} \pm 0.35$ & $1.00^{\mathrm{a}} \pm 0.28$ \\
\hline
\end{tabular}

$\mathrm{E}, \mathrm{F}$ and $\mathrm{H}=$ Different Samples; Data are presented as Mean $\pm \operatorname{SD}(n=3)$. Values with the same superscript letter down the columns are not significantly different $(p>0.05)$.

\subsection{Discussion}

\subsubsection{Heavy metal composition in the toning creams using the wet acid method}

Table 3.1 shows the level of heavy metals present in the toning creams using the wet acid method. From the table, manganese and nickel are higher in sample A. High exposure to nickel containing compounds are dangerous because they are carcinogenic. The manganese is also observed to be higher in sample $\mathrm{B}$ and sample $\mathrm{C}$, while cadmium is lower in the sample B and sample $\mathrm{C}$, and below detectable limit in sample A. The level of copper in the creams is also observed to be $3.90 \pm 0.14,7.90 \pm 0.12$ and $12.05 \pm 0.35$ for samples A, B and C, respectively. The mean levels were significantly different among the samples at $(p<0.05)$ level of significance. Chronic exposure to copper can generate 
several physiological and behavioral disturbances, which include brain damage and progressive demyelination, psychiatric disturbances - depression, suicidal tendencies and aggressive behavior - hemolytic anemia, cirrhosis of the liver, motor dysfunction and corneal opacities (U.S. EPA [15], Goyer [9]). Furthermore, chromium is relatively high in sample A using the wet acid method. In cosmetics, the oxides of chromium (Cr), chromium oxide and hydrated chrome oxide are used especially in soaps due to their colour (Butler and Poucher [2], Dayan and Paine [4]). Chromium (VI) compounds are toxic and carcinogenic. Breathing high levels of $\mathrm{Cr}$ can cause irritation to the lining of the nose, nose ulcers, running nose and breathing problems such as asthma, cough, shortness of breath, or wheezing (Dayan and Paine [4]). Long term exposure to chromium can cause damage to the liver, kidney circulatory, and nerve tissues, as well as skin irritation.

\subsubsection{Heavy metal composition in the toning creams using the dry ashing method}

The heavy metal concentration in the toning creams using the dry ashing method is observed in Table 3.2. From the table, the mean level of almost all the metals between samples E, F and G were not significantly different at level at $(p<0.05)$. Iron is higher in the three investigated toning creams, while lead is lower in the three samples. Many studies over the years have shown that lead could be harmful at very low levels. The lead can get into the body through dermal absorption (Filon et al. [6]). Although, studies on dermal absorption of lead in human are still scarce but it has been noted that damaged skin and metallic chemical structures are factors which can enhance percutaneous penetration of this metal in the body. Tsankov et al. [14] proposed that the maximum allowable concentration of lead should be $\approx 10 \mathrm{ppm}$. Lead has been found to be a common contaminant in various cosmetics (Chauhan et al. [3]). Studies have revealed that lead can be absorbed by dermal contact and may cause anemia, colic, neuropathy, nephropathy, sterility, coma, behavioral abnormalities, learning impairment among others (Nnorom et al. [11], Chauhan et al. [3]).

Zinc is also observed to be high in the three toning creams. The levels of zinc as found in this study were lower than those reported in the literature where zinc has been detected to levels as high as 56.57 ppm (Gentscheva et al. [8]). This together may be attributed to compositional differences of products as well as environmental conditions. Although, it is an essential element in both plants, animals and humans but may be toxic at levels above $40 \mathrm{ppm}$. Zinc toxicity causes irritability, muscular stiffness and pain (Deshpande [5], Al-weher [1]). 


\section{Conclusion}

As obtained in the results from the analysis, it was observed that heavy metals $(\mathrm{Cu}$, $\mathrm{Cd}, \mathrm{Cr}, \mathrm{Pb}, \mathrm{Mn}, \mathrm{Zn}$ and $\mathrm{Ni}$ ) were present in the creams. The levels, however, were lower than those set by WHO. These results do not warrant safety though for use of these products since it is evident from the literature that continuous use of cosmetics would be harmful to health. Heavy metal impurities have been acknowledged to be unavoidable in cosmetic products due to the ubiquitous characteristics of these elements. Hence, they should be removed whenever technically feasible. The differences in mean levels may be as a result of the difference in compositions, methods, and equipment of productions, packaging materials and methods of analysis. This may pose a threat, especially, where users apply a combination of these cosmetics. Therefore, manufacturers should indicate presence and levels of heavy metals on labels of products.

\section{References}

[1] M. Al-weher, Levels of heavy metals, $\mathrm{Cd}, \mathrm{Cu}$, and $\mathrm{Zn}$ in three fish species collected from the Northern Jordan Valley, Jordan Journal of Biological Sciences 6 (2008), 47-52.

[2] H. Butler and W. A. Poucher, Poucher's Perfumes, Cosmetics and Soaps, Dordrecht, Netherlands: Kluwer Academic Publishers, 2000.

[3] A. S. Chauhan, R. Bhadauria, A. K. Singh, S. S. Lodhi, D. K. Chaturvedi and V. S. Tomari, Determination of lead and cadmium in cosmetics products, Journal of Chemical and Pharmaceutical Research 2(6) (2010), 92-97.

[4] A. D. Dayan and A. J. Paine, Mechanisms of chromium toxicity, carcinogenicity and allergenicity: Review of the literature from 1985 to 2000, Human and Experimental Toxicology 20 (2001), 439-451.

[5] G. Deshpande, Handbook of Food Toxicology, UK: Taylor and Francis e-Library, 2005.

[6] F. L. Filon, F. D’Agostin, M. Crosera, G. Adami, M. Bovenzi and G. Maina, In vitro absorption of metal powders through intact and damaged human skin, Toxicology in Vitro 23(4) (2009), 574-579.

[7] G. Forte, F. Petrucci and B. Bocca, Metal allergens of growing significance: epidemiology, immunotoxicology, strategies for testing and prevention, Inflammation Allergy Drug Targets 7 (2008), 145-162.

[8] G. D. Gentscheva, T. Stafilov and E. H. Ivanova, Determination of some essential and toxic elements in herbs from Bulgaria and Macedonia using Atomic Spectrometry, Eurasian Journal of Analytical Chemistry 5 (2010), 104-111. 
[9] R. A. Goyer, Toxic effects of metals, in: Amdur, M.O., Doull, J., Klaasen C.D. (eds.) Casarett and Doull's Toxicology, 4th ed., New York, NY: Pergamon Press, 1991, pp. 653-655.

[10] P. V. Kasture, S. A. Hasan, S. B. Gokhale and S. R. Parekar, Practical Pharmaceutics - I, India: Nirali Prakashan, 2008.

[11] I. C. Nnorom, J. C. Igwe and C. G. Oji-Nnorom, Trace metal contents of facial (Make-up) cosmetics commonly used in Nigeria, African Journal of Biotechnology 4 (2005), 1133 1138 .

[12] J. A. Omolaoye, A. Uzairu and C. E. Gimba, Heavy metal assessment of some eye shadow products imported into Nigeria from China, Archives of Applied Science Research 2 (2010), 76-84.

[13] J. P. Thyssen, J. D. Johansen and T. Menné, Contact allergy epidemics and their controls, Contact Dermatitis 56 (2007), 185-195.

[14] I. Tsankov, I. Iordanova, D. Lolova, S. Uzunova and S. Dinoeva, Hygienic evaluation of the content of heavy metals (lead and copper) in cosmetic products, Problemina Khigienata 7 (1982), 127-136.

[15] U.S. EPA, Risk Assessment Guidance for Superfund, Volume I: Human Health Evaluation Manual (Part E, Supplemental Guidance for Dermal Risk Assessment), Final, EPA/540/R/99/005, Washington, DC: Office of Superfund Remediation and Technology Innovation, U.S. Environmental Protection Agency, 2004.

[16] WHO, Chromium, zinc, lead, in drinking-water, Background document for preparation of WHO Guidelines for Drinking-water Quality, Geneva: World Health Organization (WHO/SDE/WSH/03.04/4), 2003. 